\title{
A comparative analysis of financial performance of Islamic banks vis-à-vis conventional banks: evidence from Pakistan
}

\author{
Muhammad Tariq Majeed \\ Economics, Quaid-I-Azam University, Islamabad, Pakistan, and \\ Abida Zainab \\ Planning Commission, Islamabad, Pakistan
}

Financial

performance of Islamic banks

\begin{abstract}
Purpose - In recent years, the fast growth of Islamic banks (IBs) has generated debates among policymakers and economists about the sustainability and performance of these institutions. This paper aims to undertake a comparative analysis of the financial performance of IBs and conventional banks (CBs) in Pakistan over the period 2008-2019 to evaluate how IBs are faring compared to their conventional peers.

Design/methodology/approach - This paper considers Financial Ratio Analysis (FRA) to analyse and compare the performance of the top-10 IBs and CBs operating in Pakistan. The sample includes five full-fledged IBs and five CBs which offer Islamic windows in Pakistan. The top-five performing CBs offering Islamic windows have been selected in this study.

Findings - The results show that IBs are better capitalized, less risky and have higher liquidity as compared to CBs. In contrast, the profits of IBs are found to be lower than those of CBs.

Research limitations/implications - The study has provided an analysis of financial performance only for Pakistan. A cross-country analysis could be more representative of the performance of IBs.

Practical implications - The study infers that the size of the Islamic banking industry in Pakistan should be enhanced by opening new branches and promoting Islamic financial literacy.

Originality/value - The study assists investors, creditors, debtors and managers in making better decisions. It also provides the latest valuable information to regulators and policymakers that can be used to make rules and policies for the finance industry in Pakistan.
\end{abstract}

Keywords Conventional banks (CBs), Financial performance, Financial ratio analysis (FRA),

Islamic banks (IBs)

Paper type Research paper

\section{Introduction}

The surge in Islamic banking has generated debates among policymakers and economists about the sustainability and performance of Islamic banks (IBs). The literature reveals that various studies have evaluated the performance of IBs for different countries in different times, such as Rosly and Bakar (2003), Mokhtar et al. (2008), Siraj and Pillai (2012), Elsiefy (2013), Sillah et al. (2014), Setyawati et al. (2017), Daoud and Kammoun (2017), Akram and Rahman (2018), Johnes et al. (2018), Rusydiana and Sanrego (2018), Alsartawi (2019), Berger et al. (2019), Mustafa (2019), Ledhem and Mekidiche (2020) and Baeshen and Shaheen (2021).

(C) Muhammad Tariq Majeed and Abida Zainab. Published in ISRA International Journal of Islamic Finance. Published by Emerald Publishing Limited. This article is published under the Creative Commons Attribution (CC BY 4.0) licence. Anyone may reproduce, distribute, translate and create derivative works of this article (for both commercial and non-commercial purposes), subject to full attribution to the original publication and authors. The full terms of this licence maybe seen at http:// creativecommons.org/licences/by/4.0/legalcode.

Received 28 August 2018 Revised 22 December 2018 22 March 2019

17 February 2021

31 March 2021

2 June 2021

5 July 2021

Accepted 6 July 2021 
IJIF

13,3

332

In the case of Pakistan, some studies such as those by Jaffar and Manarvi (2011), Usman and Khan (2012), Ansari and Rehman (2012) and Aziz et al. (2016) have measured financial performance of IBs. However, studies conducted for Pakistan have used small samples of banks and the time frame ranges from 2006 to 2014.

Today, the growth of the Islamic banking industry cannot be denied. The global Islamic banking industry is growing at least 5\% annually (S\&P Global Ratings, 2020). The surge in Islamic banking has generated debates among policymakers and economists about the sustainability and performance of IBs. Various studies such as Johnes et al. (2018), Berger et al. (2019), Belkhaoui et al. (2020) and Ledhem and Mekidiche (2020) measured the performance of IBs using a sample of Gulf Cooperation Council (GCC) or other Muslim countries such as Malaysia, Saudi Arabia, Turkey, Brunei and Indonesia.

It is observed that evaluation of the annual financial performance of the Islamic finance industry is required for Pakistan. However, such a recent assessment, particularly after 2014, is missing in the literature. For instance, Kakakhel et al. (2013) analyze financial performance of banks utilizing data from 2008 to 2010, and a sample of just two IBs and two CBs was studied. No doubt, two studies by Saeed et al. (2013) and Siddique and Rahim (2013) used a larger dataset covering the period 2007-2012 and a larger sample of banks. Nevertheless, these studies do not measure financial performance; rather, they focus on the efficiency of IBs.

Recently, another study by Aziz et al. (2016) also measures the financial performance of IBs utilizing data from 2006 to 2014. It shows that studies using the latest datasets are missing. Besides, the previous studies do not provide clear reasons for their findings. Considering the shortcomings of previous studies, this study aims to address the following research questions:

RQ1. Do IBs perform better than CBs in Pakistan over the period 2008-2019?

$R Q 2$. What are the factors that explain the difference between the comparative performance of IBs and CBs?

This study is different from existing studies in Pakistan in several ways. First, it uses the largest available dataset for the period 2008-2019. Second, a larger sample and a different sample of banks (such as top-10 banks) are utilized. Third, a comparison of five full-fledged IBs is made with five CBs offering Islamic windows. The latter are larger in size compared to the full-fledged IBs. This practice of inter-bank evaluation is preferred when studying bank performance (Sabi, 1996). Moreover, the study not only finds comparative evidence of better/ lower performance but also helps to understand the logical reasons for each finding.

The study has essential repercussions because bank's financial performance is required by different parties such as investors, bank managers, depositors and policymakers. It indicates that financial performance evaluation is a critical topic, but studies conducted in Pakistan are somewhat outdated. The findings of this study provide details of challenges that undermine the performance of IBs, which are not well highlighted by available studies in Pakistan. Therefore, this study is helpful for investors and depositors in making better decisions regarding investments and withdrawal of funds. It also provides direction to bank managers to improve the quality of both finance and deposit services. Finally, the results of this study help financial regulators formulate appropriate policies.

\section{Literature review}

Banks utilize savings of customers and finance business activities that result in more employment opportunities, higher income levels and lower poverty. Thus, economic development relies on the banking industry's performance (Siraj and Pillai, 2012). Accordingly, assessing the performance of the finance industry has been an attention-grabbing area for researchers at all times. Many previous studies have analyzed 
the performance of CBs employing financial ratios (Reger et al., 1992; Sabi, 1996; Samad, 1999; Masruki et al., 2011; Siraj and Pillai, 2012; Beck et al., 2013; Johnes et al., 2018; Berger et al., 2019; Ledhem and Mekidiche, 2020).

As Islamic banking is an emerging industry, the literature reveals that various studies have scrutinized the functioning of IBs and CBs (see Table 1). Most of the previous studies find mixed results. For instance, Ariss (2010) analyzes the performance of IBs using H-Statistics and Lerner Index. The findings show that IBs have better capitalization and a higher share of assets to loans but are less competitive and less profitable than CBs. Similarly, Loghod (2011) examines the performance of Islamic and conventional banking systems using data from GCC countries and concludes that IBs are less risky and more independent of external funds than CBs. Still, no difference is found in profitability and internal growth.

Other studies use financial ratio analysis (FRA) and find mixed evidence about the functioning of emerging banks and CBs (Masruki et al., 2011; Siraj and Pillai, 2012; Srairi, 2013; Elsiefy, 2013). Similarly, Onakoya and Onakoya (2013) explore the performance of the conventional and Islamic financial industry in the United Kingdom. The findings show that IBs are cost-efficient, less risky and independent of external funds but are less profitable and inefficient in meeting financial obligations than CBs.

Besides, some previous studies conducted in Pakistan also conclude mixed results. IBs are found to be better in liquidity and capital adequacy but similar in asset quality and lower in profitability than CBs (Jaffar and Manarvi, 2011). IBs are also found to have higher liquidity, lower risk and higher operational efficiency than their counterparts (Ansari and Rehman, 2012). Kakakhel et al. (2013) reveal that IBs perform better in cash, asset turnover and debt-toasset but are less profitable than CBs. On the other hand, Majeed and Zanib (2016) find that full-fledged IBs are highly proficient in technical efficiency; however, they are less scale efficient than their counterparts.

In contrast, many studies find a better performance of IBs than their counterparts. For instance, Iqbal (2001) estimates the proficiency of IBs in nine Middle East countries over the period 1990-1998. Bader et al. (2008) link the Islamic and conventional finance industry's performance in Asian and Middle East countries during 1990-2009. These studies calculate financial ratios and conclude that emerging IBs are significantly more proficient than CBs.

Similarly, Rahim et al. (2013) examine the efficiency of IBs in the Middle East and North African (MENA) and Asian countries. The study finds that IBs are highly "pure technically efficient" and that IBs from Asian countries perform significantly better than IBs from MENA countries. Rosman et al. (2014) undertake the same task; however, they draw a different conclusion: that the performance of IBs is sustained during crises, but most IBs are proven to be scale inefficient.

Nonetheless, few studies find the lower performance of IBs. For example, Rosly and Bakar (2003) and Mokhtar et al. (2008) conduct studies in Malaysia and conclude that IBs exhibit slower performance than CBs. Hassan (2006) investigates the competency of IBs in Middle Eastern countries during 1995-2001 and finds that IBs are less efficient than CBs. A study conducted in Pakistan by Saeed et al. (2013) utilizes data envelopment analysis (DEA) and financial ratio analysis (FRA) techniques to scrutinize the efficiency of IBs from 2007 to 2011 and concludes that IBs are less competent than CBs.

The above debate reveals that even though up-to-date data is available, evaluation regarding the Islamic finance industry's performance in Pakistan, particularly after 2014, is missing in the literature. It is also observed that previous studies do not provide details of their conclusions. It is worth mentioning that efficiency and financial performance are two different concepts. The former is complex and cannot be understood by common people, but the latter provides useful information in figures that can easily be compared by depositors, investors, debenture holders and shareholders. Therefore, to facilitate bankers, customers and financial regulators, this study utilizes FRA considering the latest available dataset.
Financial performance of Islamic banks

333 


\begin{tabular}{|c|c|c|c|}
\hline Studies & $\begin{array}{l}\text { Study } \\
\text { period }\end{array}$ & Methods & Findings \\
\hline \multicolumn{4}{|l|}{ Cross country studies } \\
\hline Haron (1996) & 1982-1994 & OLS & IBs perform better in a competitive market \\
\hline Iqbal (2001) & 1990-1998 & $\begin{array}{l}\text { Trend and ratio } \\
\text { analysis }\end{array}$ & Better performance of IBs than CBs \\
\hline Hassan (2006) & 1995-2001 & DEA & Lower performance of IBs than CBs \\
\hline Bader et al. (2008) & 1990-2005 & DEA & Better performance of IBs than CBs \\
\hline Ariss (2010) & $2000-2006$ & $\begin{array}{l}\text { H-statistics and Lerner } \\
\text { index }\end{array}$ & Mixed results \\
\hline Srairi (2010) & 1997-2007 & SFA & Lower performance of IBs than CBs \\
\hline Loghod (2011) & 2000-2005 & Logit model and FRA & Mixed results \\
\hline Siraj and Pillai (2012) & 2005-2010 & FRA & Mixed results \\
\hline Beck et al. (2013) & 1995-2009 & FRA & Better performance of IBs than CBs \\
\hline Srairi (2013) & 2005-2009 & FRA & Mixed results \\
\hline Rahim et al. (2013) & 2006-2011 & DEA & Asian IBs perform better than MENA IBs \\
\hline Rosman et al. (2014) & $2007-2010$ & DEA & IBs perform better during crisis \\
\hline $\begin{array}{l}\text { Tlemsani and Suwaidi } \\
\text { (2016) }\end{array}$ & $2007-2008$ & FRA & IBs perform better than CBs \\
\hline Bahrini (2017) & 2007-2012 & DEA & IBs perform better during crisis \\
\hline Chokri and Anis (2018) & 2012-2014 & Regression model & Mixed results \\
\hline $\begin{array}{l}\text { Ledhem and Mekidiche } \\
(2020)\end{array}$ & 2014-2018 & CAMEL model & $\begin{array}{l}\text { Profitability determines the performance of } \\
\text { Islamic finance }\end{array}$ \\
\hline \multicolumn{4}{|l|}{ Country specific studies } \\
\hline Rosly and Bakar (2003) & 1992-1999 & FRA & Lower performance of IBs than CBs \\
\hline $\begin{array}{l}\text { Samad and Hassan } \\
\text { (1999) }\end{array}$ & 1984-1997 & FRA & Mixed results \\
\hline Mokhtar et al. (2008) & 1997-2003 & DEA & Lower performance of IBs than CBs \\
\hline $\begin{array}{l}\text { Widagdo and Ika } \\
\text { (2008) }\end{array}$ & 2004 & FRA & $\begin{array}{l}\text { No difference between performance of IBs } \\
\text { and CBs }\end{array}$ \\
\hline Masruki et al. (2011) & $2004-2008$ & FRA & Mixed results \\
\hline Elsiefy (2013) & 2006-2010 & FRA & Mixed results \\
\hline Rahim et al. (2013) & $2006-2011$ & DEA & $\begin{array}{l}\text { Foreign IBs perform better than domestic } \\
\text { IBs }\end{array}$ \\
\hline $\begin{array}{l}\text { Onakoya and Onakoya } \\
\text { (2013) }\end{array}$ & $2007-2011$ & FRA & Mixed results \\
\hline $\begin{array}{l}\text { Shamsu uddin et al. } \\
\text { (2017) }\end{array}$ & $2010-2014$ & CAMEL analysis & $\begin{array}{l}\text { No difference between performance of IBs } \\
\text { and } \mathrm{CBs}\end{array}$ \\
\hline $\begin{array}{l}\text { Mukhibad and Khafid } \\
\text { (2018) }\end{array}$ & $2009-2016$ & SEM with WarpPLS & Mixed results \\
\hline \multicolumn{4}{|l|}{ Studies involving Pakistan } \\
\hline $\begin{array}{l}\text { Jaffar and Manarvi } \\
\text { (2011) }\end{array}$ & $2005-2009$ & CAMEL analysis & Mixed results \\
\hline $\begin{array}{l}\text { Usman and Khan } \\
\text { (2012) }\end{array}$ & $2007-2009$ & FRA & Better performance of IBs than CBs \\
\hline $\begin{array}{l}\text { Ansari and Rehman } \\
\text { (2012) }\end{array}$ & $2006-2009$ & FRA & Mixed results \\
\hline Kakakhel et al. (2013) & $2008-2010$ & FRA & Mixed results \\
\hline Saeed et al. (2013) & 2007-2011 & FRA and DEA & Lower performance of IBs than CBs \\
\hline Aziz et al. (2016) & 2006-2014 & FRA & Better performance of IBs than CBs \\
\hline $\begin{array}{l}\text { Majeed and Zanib } \\
\text { (2016) }\end{array}$ & $2007-2014$ & DEA & Mixed results \\
\hline
\end{tabular}

Table 1.

Summary of studies measuring the performance of IBs
Note(s): FRA: Financial Ratio Analysis; DEA: Data Envelopment Analysis; SFA: Stochastic Frontier Approach 
Since Pakistan is one of the pioneer countries that are actively engaged in Islamic banking promotion, it is important to scrutinize the performance of the Islamic industry and find the likely causes of differences in comparative performance.

\section{Methodology \\ Sample}

This study aims to conduct a comparative analysis of the financial performance of the top ten IBs and CBs offering Islamic windows in Pakistan, as delineated in Table 2. To make an appropriate comparison, this paper utilizes cross-sectional data collected from the annual reports of the banks over the period 2008-2019, available at the official website of each bank. Even though the IBs commenced operations in 2002, complete data are accessible since 2008.

\section{Measurement technique}

This paper utilizes popular methods to calculate financial ratios of the banks. Cole (1972) introduced financial ratios to determine banks' performance. Many standard studies in the literature (for instance, Widagdo and Ika, 2008; Masruki et al., 2011; Usman and Khan, 2012; Siraj and Pillai, 2012; Elsiefy, 2013; Beck et al., 2013; Mukhibad and Khafid, 2018) have used this method for a similar purpose. This analysis usually compares profitability, liquidity, capital adequacy, risk and solvency ratios. This study also presents descriptive statistics in terms of mean, standard deviation and $t$-test to check the significance of each ratio for both types of banks. The theoretical framework in Figure 1 provides a clear picture of the methodology used in this study. The explanation of each indicator of performance is given next.

Profitability. Profitability represents marginal efficiency. This efficiency is observed by considering return on assets (ROA), equity, expense and investment. Higher profitability

\begin{tabular}{ll}
\hline IBs & CBs \\
\hline Meezan bank limited (MBL) & Habib bank limited (HBL) \\
Burj bank (BB) & Faysal bank (FB) \\
Al-Baraka bank (ABB) & Bank Alfalah (BA) \\
Dubai Islamic bank (DIB) & Askari bank (AB) \\
Bank Islami (BI) & Bank of Khyber (BoK) \\
\hline
\end{tabular}

Financial performance of Islamic banks

335


IJIF

13,3

\section{6}

promotes constant growth of capital to protect creditors against default risk. Profitability ratios are used to quantify the performance of banks (Elsiefy, 2013). This study computes ROA and returns on equity (ROE). Although ROE is correlated with ROA, it is different in terms of magnitude and interpretation (Simpson and Kohers, 2002; Karr, 2005; Castelli et al., 2006). These profitability ratios have also been considered by Reger et al. (1992), Ansari and Rehman (2012), and Elsiefy (2013). A higher value of the ratios indicates more profit.

Liquidity. Liquidity risk involves the withdrawal of money deposited in current and savings accounts at any time. A bank faces a liquidity problem in the case of excessive withdrawals as compared to new deposits in a short period. The liquidity of banks determines their ability to manage liquidity crises. A weak liquidity position can lead to a bank's failure. Following the studies by Hays et al. (2009), Rose and Hudgins (2010), Ansari and Rehman (2012) and Onakoya and Onakoya (2013), this study quantifies loan-to-asset ratio (LAR) and loan-to-deposits ratio (LDR) to estimate liquidity.

Capital adequacy. It describes a bank's capacity to fulfill its financial obligations at the time of economic stress. To protect against unanticipated failure, the bank's capital must be adequate. The State Bank of Pakistan requires banks to have a $10 \%$ capital adequacy ratio (CAR). A higher value of CAR represents financial soundness and lower risk for the bank. To inspect capital adequacy, this study follows Rose and Hudgins (2010), Masruki et al. (2011) and Siraj and Pillai (2012) and uses equity-to-liability (ELR) and equity-to-asset (EAR) ratios.

Risk and solvency. It indicates the ability of a bank to generate income and to pay long-term debts. A bank is considered solvent when its total assets exceed equity. Several methods can be used to measure solvency ratios. This study calculates the debt-to-asset ratio (DAR) and debt-to-equity ratio (DER). These ratios have also been computed by Samad and Hassan (1999), Olson and Zoubi (2008) and Elsiefy (2013).

It is worth mentioning that each indicator of financial performance can be computed by using one formula. However, to check robustness, two formulae for each indicator of financial performance are used. All formulas are given in Table 3.

\section{Empirical findings and discussion}

This section presents the statistical and graphical analysis of each financial ratio. First, profitability ratios are considered. Figure 2 shows that ROA is positive for IBs in the initial years but turns into losses during the financial crisis (2008-2010). A careful study of the annual report of Bank Islami (2014) reveals that during the financial crisis, the bank's operating expenses and administrative costs increased. Nevertheless, after the financial crisis, the ROA of IBs as well as CBs was restored to a positive condition and continued to increase until 2013.

\begin{tabular}{|c|c|c|}
\hline $\begin{array}{l}\text { Indicators of financial } \\
\text { performance }\end{array}$ & Measurements & Formulae \\
\hline \multirow[t]{2}{*}{ Profitability } & $\mathrm{ROA}$ & Profit after tax/Total assets $* 100$ \\
\hline & $\mathrm{ROE}$ & Profit after tax/Total equity $* 100$ \\
\hline \multirow[t]{2}{*}{ Liquidity } & LDR & $\begin{array}{l}\text { Due to financial institutions/Deposits and other accounts } \\
* 100\end{array}$ \\
\hline & LAR & Due to financial institutions/Total assets $* 100$ \\
\hline \multirow[t]{2}{*}{ Capital adequacy } & EAR & Total equity/Total assets $* 100$ \\
\hline & ELR & Total equity/Total liability * 100 \\
\hline \multirow{2}{*}{ Risk and solvency } & DAR & Total liability/Total assets $* 100$ \\
\hline & DER & Total liability/Total equity $* 100$ \\
\hline
\end{tabular}

Table 3.

Source(s): Masruki et al. (2011), Siraj and Pillai (2012) and Elsiefy (2013). 
Return on Assets

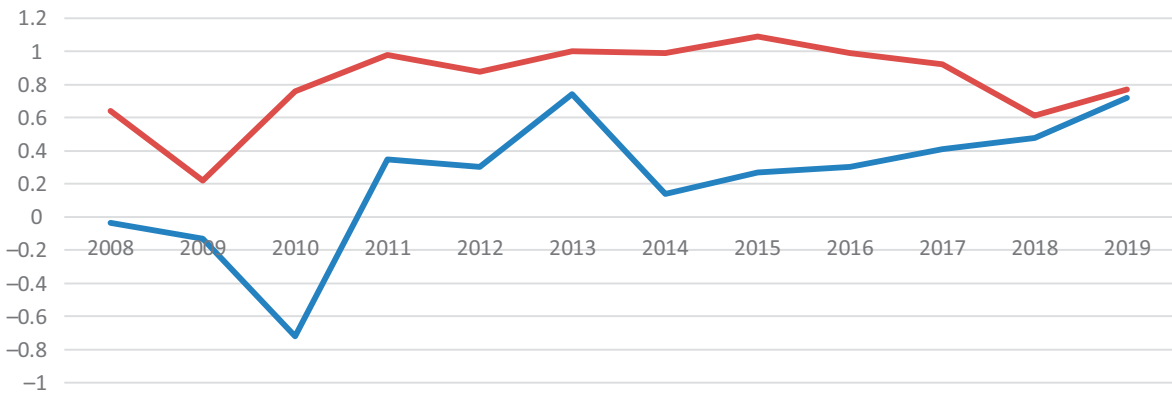

$\longrightarrow \mathrm{Bs} \longrightarrow \mathrm{CBs}$

Return on Equity

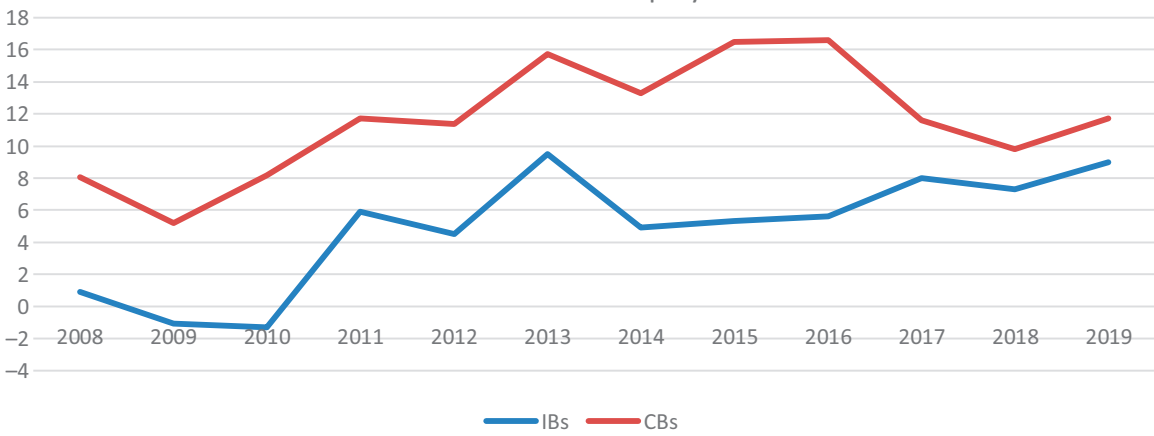

Source(s): Authors' own
Financial performance of Islamic banks
Figure 2. Profitability ratios

It is observed that the ROA of IBs decreased in 2014 because of a decline in investment. Indeed, State Bank of Pakistan (2014) disclosed that investment remained low due to non-availability of $i j \bar{a} r a h$ sukuk (lease certificates). However, the ROA of IBs consistently increased during 2015-2016; it increased sharply in 2017 and continued to increase until 2019. This is because of increasing assets of IBs after 2015, particularly in 2017, when the assets of the overall Islamic banking industry witnessed a growth of $22.6 \%$ (State Bank of Pakistan, 2017). In contrast, the ROA of CBs has slightly decreased over the period 2015-2018 but it was still higher than that of IBs.

Similarly, Figure 3 shows that the ROE of IBs was low during 2008 as it was hit by the financial crisis. Later, the ROE of IBs was restored to some extent after the crisis. Finally, it improved in 2013 up to $9.5 \%$. However, in 2014, it decreased sharply due to a decline in investment and financing. After 2014, investment and financing of IBs increased, which resulted in a better return on equity during 2015-2019. In contrast, the ROE of CBs was high and remained positive over the period 2015-2019. However, it also declined sharply during the crisis but then was later restored after the crisis.

The ROE of IBs declined sharply in 2014 as compared to CBs during the same period because of a decline in investment and financing. The higher ROE of CBs is due to their efficient management of equity. Nonetheless, after 2014 investment and financing of IBs increased, which resulted in a better ROE over the period 2015-2019. 
IJIF

338

Figure 3.

Liquidity ratios
Loan to Assets

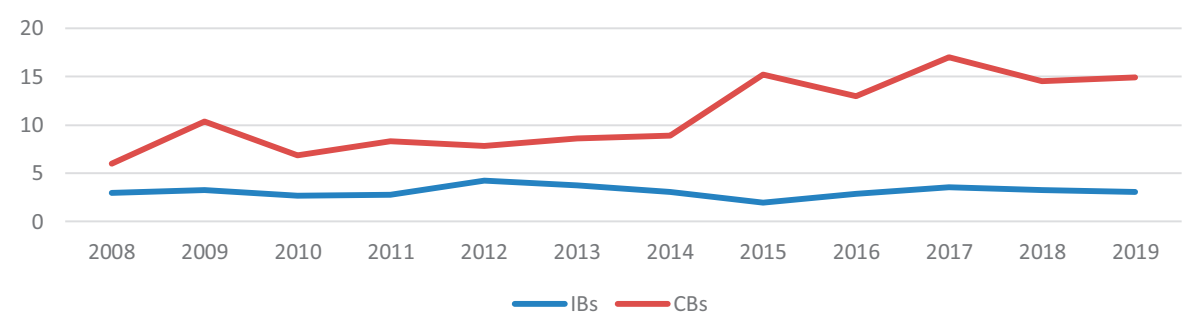

Loan to Deposits

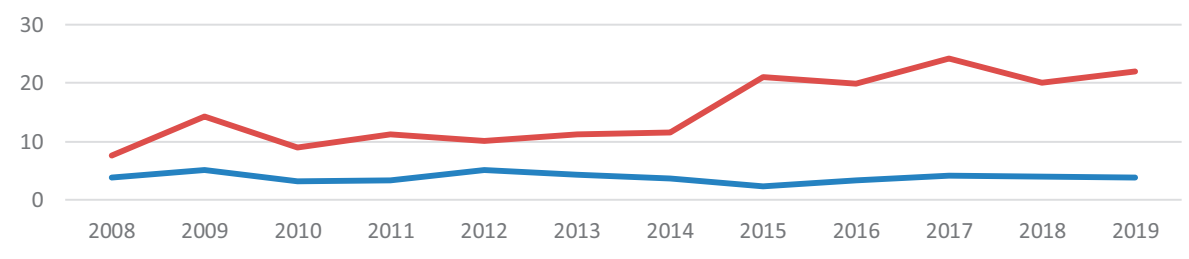

$\longrightarrow$ IBs $\longrightarrow$ Bs

Source(s): Authors' own

Similarly, the mean values of profitability ratios such as ROA and ROE indicate that the profitability of IBs remained low at $0.5 \%$ and $4.6 \%$, respectively as compared to $0.9 \%$ and $11.4 \%$, respectively for their counterpart throughout the tenure of the research (see Table 4). $P$-values show that difference in mean values is significant at the $5 \%$ level of significance. These results are confirmed by Masruki et al. (2011), Elsiefy (2013) and Onakoya and Onakoya (2013).

The reason for the lower profitability of IBs is three-fold. First, the small size of IBs is an obstacle in the way of benefitting from economies of scale, which ultimately leads to lower profitability. Lindblom (2002) emphasizes that if the size of comparable banks is different, then profitability ratios cannot be estimated accurately. Second, interest-free transactions and services cause lower profitability. It is verified by Hancock (1985), who observes that

Table 4.

Descriptive statistics: IBs and CBs' financial performance (2008-2019)

\begin{tabular}{lccccccc}
\hline & $\begin{array}{c}\text { Mean IB } \\
(\%)\end{array}$ & $\begin{array}{c}\text { Std. Deviation } \\
\text { IB }\end{array}$ & $\begin{array}{c}\text { Mean CB } \\
(\%)\end{array}$ & $\begin{array}{c}\text { Std. Deviation } \\
\text { CB }\end{array}$ & $\begin{array}{c}t \text {-test (equality of mean) } \\
\text { sig. (2-Tailed) } \\
\text { p-value }\end{array}$ & Inference \\
Ratios & 0.5 & 0.65 & 0.9 & 0.37 & -2.7 & 0.011 & REJ H \\
ROA & 0.6 & 4.6 & 11.4 & 4.0 & -3.2 & 0.003 & REJ H \\
ROE & 4.0 & 0.92 & 10.2 & 2.0 & -5.2 & 0.000 & REJ H \\
LDR & 5.0 & 0.73 & 7.9 & 1.3 & -3.0 & 0.000 & REJ H \\
LAR & 4.0 & 9.8 & 8.5 & 1.3 & 3.9 & 0.000 & REJ H \\
EAR & 17.9 & 19.8 & 9.6 & 1.2 & 4.3 & 0.000 & REJ H \\
ELR & 25.9 & 13.8 & 91.1 & 1.1 & -3.0 & 0.005 & REJ H \\
DAR & 83.0 & 296.5 & 1258.0 & 100.0 & -4.1 & 0.000 & REJ H \\
DER & 770.0 & & & & & \\
Source(s): Computer generated & & & & & &
\end{tabular}


bank profitability depends upon interest rate and that there is a positive association between interest rate and bank profits. This means that bank profits increase with a rise in interest rate and vice versa. Third, the lower quality of their assets is attributed to the lower profitability of IBs. In contrast, the higher profitability of CBs is not surprising because they are large in asset size, competitive and allocate finance to profitable businesses.

\section{Liquidity}

Liquidity ratios help to understand whether banks can repay short-term debts and meet their obligations to creditors. Being liquid indicates the ability of banks to fulfil short-term financial obligations. In short, better liquidity represents better financial performance of a bank. First, loan-to-assets ratio (LAR) is considered. It represents the proportion of a bank's assets that are financed through loans. A lower ratio means better liquidity position of a bank. Empirical results in Figure 3 reveal that the LAR of IBs remains low with slight fluctuations throughout the study period. It is observed that IBs finance their assets by taking loans. However, the LAR of IBs does not cross $5 \%$.

On the other hand, the LAR of CBs remained higher than 5\% during 2008-2013 and continuously increased up to $14.9 \%$ during $2014-2019$. This implies that if more creditors demand repayment of loans, the risks of default for $\mathrm{CBs}$ will increase. Moreover, a higher LAR negatively affects the borrowing ability of CBs. On average, the lower LAR of IBs highlights their better liquidity position vis-à-vis CBs.

Moreover, loan-to-deposits ratio (LDR) represents the proportion of loans offered by banks out of deposits. A higher ratio of the LDR reflects a lower liquidity position of the bank. It suggests that CBs can earn profits by advancing more loans. In contrast, a lower ratio of LDR reveals a better liquidity position of the bank. Estimated results in Figure 3 show that the LDR for IBs remained between 3\% and 5\% from 2008 to 2019. IBs face the issue of liquidity management because of their different assets portfolio such as murābahah (cost plus) and ijārah (lease) contracts. Secondary reserves such as treasury bills and shortterm government securities options are available for CBs while for IBs such options are quite limited owing to their obligations for Shari'ah-compliant investment and asset backed finance requirements. The option of sukuk is limited in Pakistan because of the difference of opinion and limited scope. On the other hand, the LDR of CBs remained between $9 \%$ and $14 \%$ during 2008-2013; however, it increased sharply to 24\% during 2014-2019. This indicates that CBs have been granting more loans from deposits than IBs. In addition, Table 4 shows that mean values for liquidity ratios such as LAR and LDR are higher at 7.9\% and $10.2 \%$ respectively for CBs than $4 \%$ and $5 \%$ respectively for IBs. $p$-value of LDR and LAR is 0.000 . It ascertains the significant difference between the liquidity position of IBs and CBs. These findings are consistent with Jaffar and Manarvi (2011).

The higher liquidity ratio of CBs reveals that CBs offered a significant amount of loans and faced financial pressure throughout the study period. Indeed, CBs are interested in making profits without considering the legality of the contract. Often, they prefer to invest in the derivatives market or finance highly profitable businesses such as the tobacco and entertainment industry. On the contrary, IBs are concerned with divine restrictions such as the prohibition of investing in unethical activities such as gambling and interest-based products. Besides, financing in IBs is always backed by real assets. The issue of liquidity management is indeed more challenging in the case of IBs because they are bound to invest merely in real assets. IBs also have extra checks and balances which increase their transaction costs. Furthermore, surplus funds in IBs escalate expenses and liabilities until the funds are invested. In general, IBs have limited Sharỉah-compliant investment options available as compared to the investment options available to CBs. IBs also have Shariah restrictions to sell debts in the secondary markets. They have limited scope for Islamic
Financial performance of Islamic banks 
IJIF

13,3

\section{0}

Figure 4.

Capital adequacy ratios securities as they can sell debt-based șukuk only in primary markets. On average, results show lower liquidity ratios of IBs as compared to CBs. These findings are consistent with Haron (1996) and Jaffar and Manarvi (2011).

\section{Capital adequacy}

Capital adequacy ratio (CAR) gives a true picture of the financial strength of banks. A higher value of CAR represents financial soundness and lower risk for the bank. Equity-to-asset ratio (EAR) represents the relative proportion of total equity from total assets of a bank. A higher ratio of EAR signifies that the assets of the bank are independent of external funds. Figure 4 discloses that the EAR of IBs is significantly higher than those of CBs in 2008. This represents the good financial health of IBs in 2008. The reasons are their lower investment activities and their independency from external funds.

However, after 2008 IBs could not maintain good financial health due to the expansion of the industry. In fact, the extension of the branch network increased the dependency of IBs on external funds. In addition, the investment activities of IBs also increased after 2008. As a result, the EAR of IBs declined continuously until 2019. On the other hand, the EAR of CBs remained low and stable. This clearly indicates the higher dependency of CBs on external funds during 2008-2019.

Equity-to-liability ratio (ELR) represents the adequacy of shareholders' equity to absorb a possible loss due to the credit risk of the financing portfolio of banks. A higher ratio indicates that the bank has a higher ability to absorb credit losses. Figure 4 shows that the ELR of IBs was very high in 2008. This shows that IBs' initial capacity to absorb credit losses was quite high. Nonetheless, the ratio decreased sharply in 2010 and continued to fall until 2019. This is
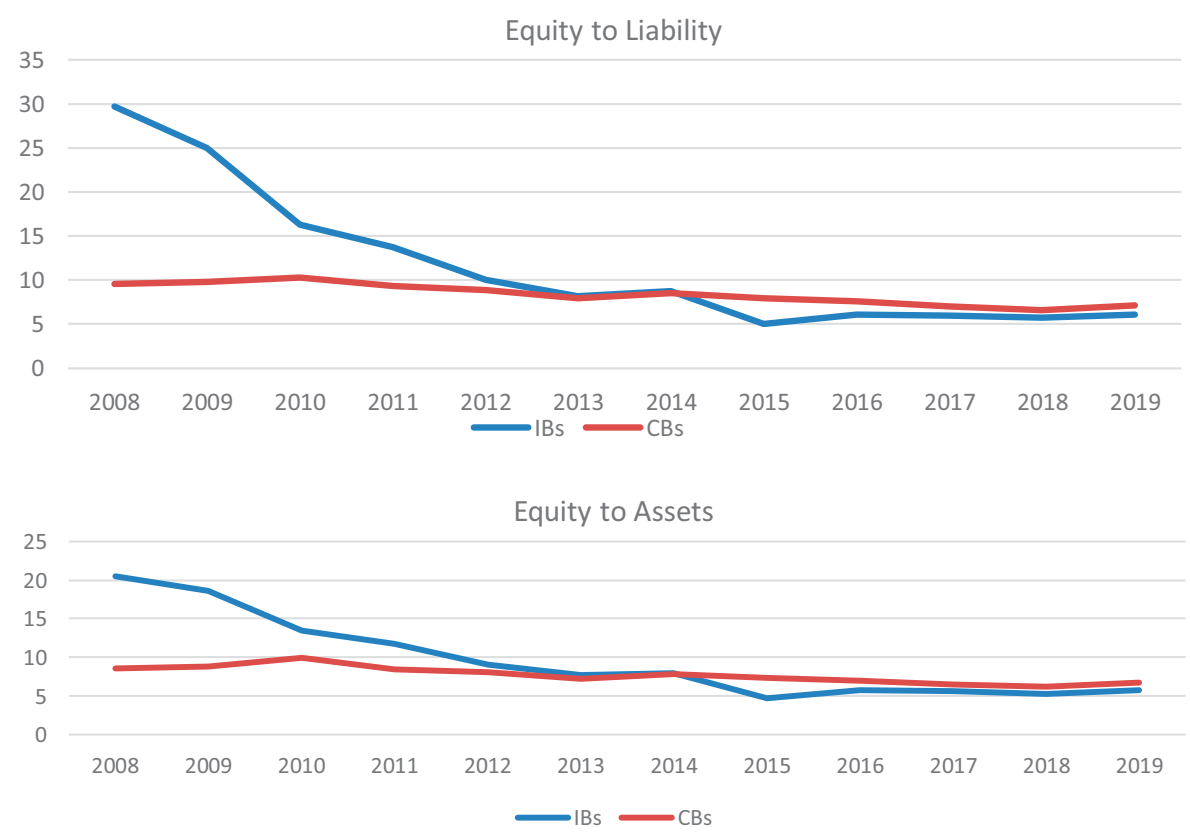

Source(s): Authors' own 
attributable to the expansion of investment activities by IBs after 2008. In contrast, the value of ELR for CBs remained stable with slight fluctuations over the period of the study. Moreover, the means value for capital adequacy in Table 4 also points out that EAR and ELR are considerably higher for IBs as compared to their counterparts. This variation is statistically significant at $1 \%$.

Overall, the CAR of IBs declined throughout the study period, although the banks still met their CAR criteria. On average, the CAR of IBs is higher as compared to CBs. These results are consistent with Elsiefy (2013), who comparatively determines the performance of IBs versus CBs in Qatar over the period 2006-2010. Better capitalization of IBs is attributed to the efficient management of risk.

\section{Risk and solvency ratios}

Risk and solvency ratios are often used to evaluate the soundness of banks. These ratios are valuable tools to analyze a bank's present and future positions of financial stability. For example, liability-to-assets ratio (LAR) describes how much of the banks' total assets are being financed by liabilities and creditors. A high value of LAR implies a high level of leverage and a high level of risk for the bank. Figure 5 reveals that LAR for IBs remained high during 2008-2014.

In contrast, the LAR of CBs ranged between $89 \%$ and $92 \%$ during the study period. This suggests a higher level of risk for CBs. It is also observed that the LAR of IBs is itself not small. Nevertheless, it is smaller than that of CBs. This leads to the conclusion that both types of banks face higher risk of default, which also lessens their borrowing capacity. On average, IBs prove to be less risky as compared to CBs during 2008-2019.

Liability-to-equity ratio (LER) specifies the proportion of equity that is used by the bank to finance its assets. A higher LER indicates that the bank is aggressively financing its growth through debt. This results in lower profitability because of additional interest expenditures.
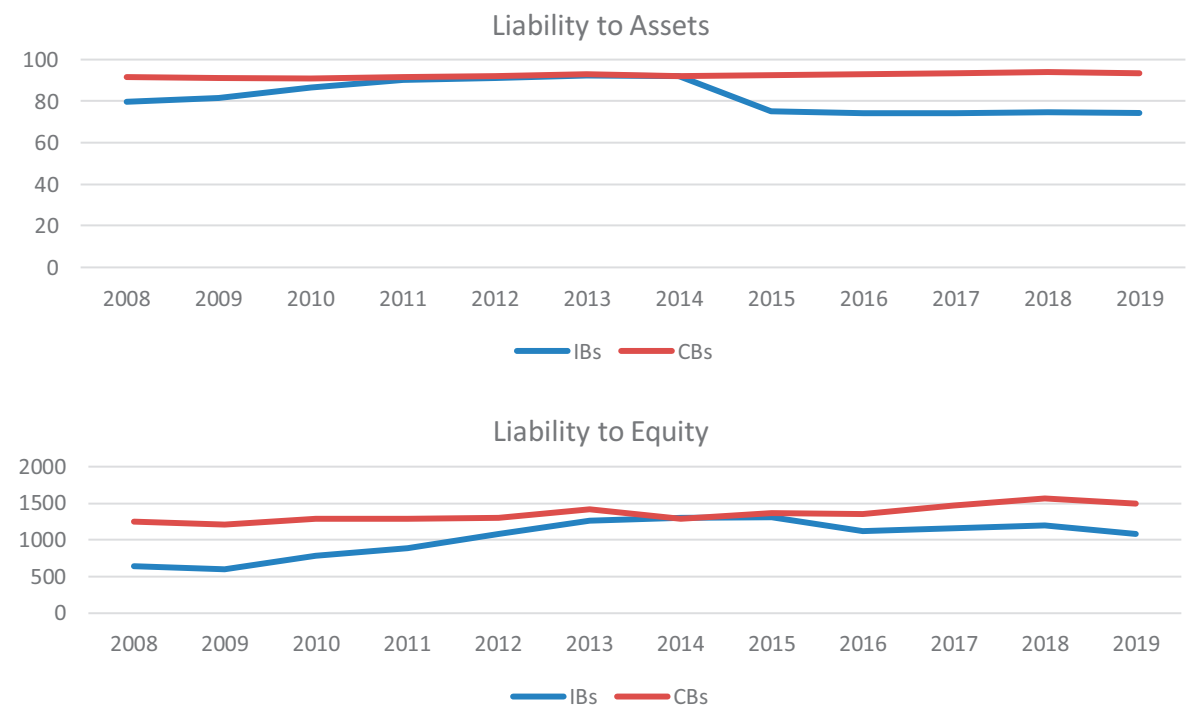

Source(s): Authors' own

Figure 5. Risk and solvency ratios 
IJIF

13,3

\section{2}

Our estimated results show a lower LER for IBs over the period 2008-2010. This suggests that IBs utilize less leverage and have a strong equity position. However, in later years IBs undertook more leverage and their liquidity position became weak. In contrast, the results uncover that the LER of CBs is very high during the study period. This shows that CBs mostly financed their growth through debt. Such financing increases the burden of interest, which results in lower earnings.

Furthermore, Table 4 indicates that the mean values of LAR and LER are smaller for IBs than CBs disclosing lower level of risks and more solvency for IBs. $P$-values are 0.005 and 0.000 for LAR and LER respectively, supporting that the difference is significant. In sum, IBs are less risky and more solvent than CBs. These findings are confirmed by Samad and Hassan (1999), Ansari and Rahman (2012), Elsiefy (2013) and Onakoya and Onakoya (2013). In fact, interest-free payments contribute to lower risk of IBs. However, it also restricts their access to funding. Besides, IBs employ less loans to acquire assets and do not finance growth through debt. The summary of the overall results is given in Table 5.

\section{Conclusion and policy implications}

This study finds that over the study period 2008-2019, the sampled IBs in Pakistan have higher liquidity, are better capitalized and are less risky than the sampled CBs. Higher liquidity is attributable to stringent financial policies. The liquidity of IBs is high due to the shortage of Islamic financial instruments. This shortage creates a problem for IBs to employ their surplus liquid funds in the market. Better capitalization is owed to efficient management of risk. The risk remains low because IBs employ fewer loans to acquire assets and do not finance growth through debt.

Furthermore, the reason for the better practices of IBs is that the State Bank of Pakistan has taken various steps to ensure improvement in the role of the Shari'ah supervisory board. Besides, the State Bank of Pakistan has introduced new measures to certify standardization and efficient management of the Islamic financial system.

Moreover, this paper finds that IBs have a lower profitability than CBs. This is because of several reasons such as a large proportion of their financing being attributed to nonperforming loans. The lower quality of their assets contributes to their lower profitability. The relatively small asset size of IBs is also a hurdle in achieving economies of scale. In the same manner, being an emerging industry, IBs bear high costs of marketing, promotional activities and investment in technology. In addition, IBs do not have a separate central bank, and the taxation system is also not supportive of Islamic banking. Also, as Choudhury (2001)

\begin{tabular}{|c|c|c|c|c|}
\hline $\begin{array}{l}\text { Indicators of } \\
\text { financial } \\
\text { performance }\end{array}$ & $\mathrm{CB}$ & Logical reasoning & $\mathrm{IB}$ & Logical reasoning \\
\hline Profitability & High & $\begin{array}{l}\text { Size of the bank, loans to profitable } \\
\text { businesses, high quality of assets, } \\
\text { interest-based operation }\end{array}$ & Low & $\begin{array}{l}\text { More interest-free, } \\
\text { ethical investment }\end{array}$ \\
\hline Liquidity & Low & $\begin{array}{l}\text { Lack of cash and other liquid } \\
\text { assets }\end{array}$ & High & $\begin{array}{l}\text { Strict financial } \\
\text { policy }\end{array}$ \\
\hline Capital adequacy & Low & Mismanagement of risk & High & $\begin{array}{l}\text { Efficient } \\
\text { management of risk }\end{array}$ \\
\hline $\begin{array}{l}\text { Risk and } \\
\text { solvency }\end{array}$ & $\begin{array}{l}\text { High risk, } \\
\text { low } \\
\text { solvency }\end{array}$ & $\begin{array}{l}\text { Take more loans, heavy loan } \\
\text { default }\end{array}$ & $\begin{array}{l}\text { Low risk, } \\
\text { high } \\
\text { solvency }\end{array}$ & $\begin{array}{l}\text { Do not grow } \\
\text { through debt, } \\
\text { minor default }\end{array}$ \\
\hline
\end{tabular}

Table 5.

Summary of results

\footnotetext{
Source(s): Authors' own
} 
criticizes, the core Islamic financial agreements, for instance, mushärakah (profit-and-loss sharing) and mudạarabah (profit sharing) are faced with ethical and technical problems. All these factors contribute to lower profits of IBs in Pakistan.

In sum, with a small share in the financial industry, IBs are performing better in Pakistan with the support of the central bank. This suggests that there is space to improve their performance by increasing the share of IBs. On this ground, merger of IBs to increase their asset size is suggested. As up-to-date evaluation of IBs and CBs is required to be undertaken every year, this represents a noticeable area for future research. Moreover, the research can be expanded to study why IBs are not growing in Pakistan as expected as they still represent less than $5 \%$ of total banking assets.

\section{References}

Akram, H. and Rahman, K.U. (2018), "Credit risk management a comparative study of Islamic banks and conventional banks in Pakistan", ISRA International Journal of Islamic Finance, Vol. 10 No. 2, pp. 185-205.

Alsartawi, A.M. (2019), "Performance of Islamic banks: do the frequency of Shariah supervisory board meetings and independence matter", ISRA International Journal of Islamic Finance, Vol. 11 No. 2, pp. 303-321.

Ansari, S. and Rehman, A. (2012), "Financial performance of Islamic and conventional banks in Pakistan: a comparative study", 8th International Conference on Islamic Economics and Finance, pp. 1-19.

Ariss, R.T. (2010), “Competitive conditions in Islamic and conventional banking: a global perspective", Review of Financial Economics, Vol. 19 No. 3, pp. 101-108.

Aziz, S., Husin, M.M. and Hashmi, S.H. (2016), "Performance of Islamic and conventional banks in Pakistan: a comparative study", International Journal of Economics and Financial Issue, Vol. 6 No. 4, pp. 1383-1391.

Bader, M., Shamsher, M., Mohamed, A. and Hassan, T. (2008), "Cost, revenue and profit efficiency of Islamic versus conventional banks", Islamic Economic Studies, Vol. 15 No. 2, pp. 1-54.

Baeshen, L. and Shaheen, R. (2021), "Analysis of performance of Islamic banks in Saudi Arabia", PalArch's Journal of Archaeology of Egypt/Egyptology, Vol. 18 No. 13, pp. 194-202.

Bahrini (2017), "Efficiency analysis of Islamic banks in the Middle East and North Africa region: a bootstrap DEA approach”, International Journal of Financial Studies, Vol. 5 No. 1, pp. 1-13.

Bank Islami (2014), “Annual report 2014”, available at: https://bankislami.com.pk/wp-content/uploads/ 2017/04/BankIslami-Annual-Report-2014.pdf (accessed 30 March 2018).

Beck, T., Demirgüç-Kunt, A. and Merrouche, O. (2013), "Islamic vs conventional banking: business model, efficiency and stability", Journal of Banking and Finance, Vol. 37 No. 2, pp. 433-447.

Belkhaoui, S., Alsagr, N. and Hemmen, S.F.V. (2020), "Financing modes, risk, efficiency and profitability in Islamic banks: modeling for the GCC countries", Economics and Finance, Vol. 8 No. 1, pp. 1-25.

Berger, A.N., Boubakri, N., Guedhami, O. and Li, X. (2019), "Liquidity creation performance and financial stability consequences of Islamic banking: evidence from a multination studies", Journal of Financial Stability, Vol. 44 No. 1, pp. 1-18.

Castelli, A., Dwyer, J. and Hasan, G.P. (2006), Bank Relationships and Small Firms' Financial Performance, Working Paper, Federal Reserve Bank of Atlanta.

Chokri, T. and Anis, E.A. (2018), "Measuring the financial performance of Islamic banks in selected countries", Journal of Business and Financial Affairs, Vol. 7 No. 1, pp. 1-5.

Choudhury, M.A. (2001), "Islamic venture capital: a critical examination”, Journal of Economic Studies, Vol. 28 No. 1, pp. 14-33.

Financial
performance of
Islamic banks 
IJIF

13,3

344

Cole, D.W. (1972), "Return on equity model for banks", The Bankers Magazine, Summer, p. 155.

Daoud, Y. and Kammoun, A. (2017), "Financial performance analysis of Islamic banks in Tunisia", Asian Economic and Financial Review, Vol. 7 No. 8, pp. 780-789.

Elsiefy, E. (2013), "Comparative analysis of Qatari Islamic banks performance versus conventional banks before, during and after the financial crisis", International Journal of Business and Commerce, Vol. 3 No. 3, pp. 11-41.

Hancock, D. (1985), "Bank profitability, interest rates, and monetary policy”, Journal of Money, Credit and Banking, Vol. 17 No. 2, pp. 189-202.

Haron, S. (1996), "Competition and other external determinants of the profitability of IBs", Islamic Economic Studies, Vol. 4 No. 1, pp. 1-16.

Hassan, M.K. (2006), “The x-efficiency in IBs”, Islamic Economic Studies, Vol. 13 No. 2, pp. 1-30.

Hays, F., Lurgio, S.D. and Gilbert, A.H. Jr (2009), "Efficiency ratios and community bank performance", Journal of Finance and Accountancy, Vol. 1 No. 1, pp. 1-15.

Iqbal, M. (2001), "Islamic and conventional banking in the nineties: a comparative study", Islamic Economic Studies, Vol. 8 No. 2, pp. 1-28.

Jaffar, M. and Manarvi, I. (2011), "Performance comparison of Islamic and conventional banks in Pakistan", Global Journal of Management and Business Research, Vol. 11 No. 1, pp. 1-7.

Johnes, J., Izzeldin, M., Pappas, V. and Alexakis, C. (2018), "Performance and productivity in Islamic and conventional banks: evidence from the global financial crisis", Economic Modelling, Vol. 79 No. 1, pp. 1-33.

Kakakhel, S.J., Faryal, R. and Muhammad, T. (2013), "A study of performance comparison between conventional and Islamic banking in Pakistan”, Abasyn Journal of Social Sciences, Vol. 6 No. 2, pp. 1-15.

Karr, J. (2005), "Performance measurement in banking: beyond ROE", Journal of Performance Measurement, Vol. 18 No. 2, pp. 56-70.

Ledhem, M.A. and Mekidiche, M. (2020), "Economic growth and financial performance of Islamic banks: a CAMELS approach", Islamic Economic Studies, Vol. 28 No. 1, pp. 1-16.

Lindblom, T.V. (2002), "Cross-border bank mergers and acquisitions in the EU", The Service Industries Journal, Vol. 22 No. 4, pp. 41-72.

Loghod, H.A. (2011), Do Islamic Banks Perform Better than Conventional Banks? Evidence from Gulf Cooperation Council Countries, Working Paper, Arab Planning Institute, pp. 1-28.

Majeed, M.T. and Zanib, A. (2016), "Efficiency analysis of Islamic banks in Pakistan”, Humanomics, Vol. 32 No. 1, pp. 19-32.

Masruki, R., Ibrahim, N., Osman, E. and Wahab, H.A. (2011), "Financial performance of Malaysian founder Islamic banks versus conventional banks", Journal of Business and Policy Research, Vol. 6 No. 2, pp. 1-13.

Mokhtar, A., Abdullah, N. and Alhabshi, S.M. (2008), "Efficiency and competition of Islamic banking in Malaysia", Humanomics, Vol. 24 No. 1, pp. 1-21.

Mukhibad, H. and Khafid, M. (2018), "Financial performance determinant of Islamic banking in Indonesia”, Jurnal Keuangan dan Perbankan, Vol. 22 No. 3, pp. 1-12.

Mustafa, O.A. (2019), "Assessment of the financial performance of Islamic commercial banks in Sudan under credit risk and inflation pressures (1995-2017)", Journal of Islamic Banking and Finance, Vol. 7 No. 3, pp. 14-26.

Olson, D. and Zoubi, T. (2008), "Using accounting ratios to distinguish between Islamic and conventional banks in the GCC region”, The International Journal of Accounting, Vol. 43 No. 1, pp. 45-65. 
Onakoya, A.B. and Onakoya, A.O. (2013), "The performance of conventional and Islamic banks in the United Kingdom: a comparative analysis", Journal of Research in Economics and International Finance, Vol. 2 No. 2, pp. 29-38.

Rahim, R., Kadri, N. and Ismail, F. (2013), Efficiency Performance of Malaysian Islamic Banks, Munich Personal RePEc Archive, Munich, pp. 1-30.

Reger, R.K., Duhaime, I.M. and Stimpert, J.L. (1992), "Deregulation, strategic choice, risk and financial performance”, Strategic Management Journal, Vol. 13 No. 3, pp. 189-204.

Rose, P. and Hudgins, S. (2010), Bank Management and Financial Services, McGraw- Hill/Irwin, New York.

Rosly, A. and Bakar, A. (2003), "Performance of Islamic and mainstream banks in Malaysia", International Journal of Social Economics, Vol. 30 No. 12, pp. 1-17.

Rosman, R., Wahab, N.A. and Zainol, Z. (2014), "Efficiency of Islamic banks during the financial crisis: an analysis of Middle Eastern and Asian countries", Pacific-Basin Finance Journal, Vol. 28, pp. 76-90.

Rusydiana, A.S. and Sanrego, Y.D. (2018), "Measuring the performance of Islamic banking in Indonesia: an application of maslahah-efficiency quadrant (MEQ)", Journal of Islamic Monetary Economics and Finance, Vol. 3 No. 1, pp. 79-98.

Sabi, M. (1996), "Comparative analysis of foreign and domestic bank operation in Hungary", Journal of Comparative Economics, Vol. 22 No. 2, pp. 179-188.

Saeed, S., Ali, F., Adeeb, B. and Hamid, M. (2013), "Examining efficiency of Islamic and conventional banks in Pakistan: using data envelopment analysis", Global Journal of Management and Business Research, Vol. 13 No. 10, pp. 1-14.

Samad, A. (1999), "Comparative efficiency of the Islamic bank vis-a-vis conventional banks in Malaysia", Journal of Economics and Management, Vol. 7 No. 1, pp. 1-12.

Samad, A. and Hassan, M.K. (1999), "The performance of Malaysian bank during 1984-1997: an exploratory study”, International Journal of Islamic Financial Services, Vol. 1 No. 3, pp. 1-14.

Setyawati, I., Suroso, S., Suryanto, T. and Nurjannah, D.S. (2017), "Does financial performance of Islamic banking is better? Panel data estimation", European Research Studies, Vol. 20 No. 2, pp. 592-599.

Shamsu Uddin, M., Ahsan, M.K. and Haque, M.A. (2017), "Comparisons of financial performance of Islamic banks and conventional banks in Bangladesh", ABC Research Alert, Vol. 5 No. 2, pp. 9-20.

Siddique, M.A. and Rahim, M. (2013), "Efficiency analysis of full-fledge Islamic banks and standalone Islamic branches of conventional banks in Pakistan: a comparative study for the period of 20072012", Journal of Islamic Business and Management, Vol. 3 No. 2, pp. 1-21.

Sillah, B.M., Khokhar, I. and Khan, M.N. (2014), "The performance of Saudi banking industry 20002011: have the banks distinguished themselves from one another?", International Journal of Financial Research, Vol. 5 No. 2, pp. 1-12.

Simpson, W.G. and Kohers, T. (2002), "The link between corporate social and financial performance: evidence from the banking industry", Journal of Business Ethics, Vol. 6 No. 35, pp. 97-109.

Siraj, K. and Pillai, P.S. (2012), "Comparative study on performance of Islamic banks and conventional banks in GCC region”, Journal of Applied Finance and Banking, Vol. 2 No. 3, pp. 123-161.

Srairi, S.A. (2010), "Cost and profit efficiency of conventional and Islamic banks in GCC countries", The Journal of Productivity Analysis, Vol. 34, pp. 45-62.

Srairi (2013), "A comparison of the profitability of Islamic and conventional banks: the case of GCC countries", Bankers, Markets and Investors, Vol. 98 No. 1, pp. 16-27.

State Bank of Pakistan (2014), Islamic Banking Bulletin, State Bank of Pakistan, available at: https:// www.sbp.org.pk/ibd/bulletin/2014/IBB-Dec-2014.pdf (accessed 07 November 2020).
Financial
performance of Islamic banks 
IJIF

13,3

346

State Bank of Pakistan (2017), Islamic Banking Bulletin, State Bank of Pakistan, available at: http:// www.sbp.org.pk/ibd/bulletin/2017/IBB-Mar-2017.pdf (accessed 07 November 2020).

S\&P Global Ratings (2020), "Islamic finance outlook 2020", available at: https://www.spglobal.com/_ assets/documents/ratings/research/islamic_finance_2020_screen.pdf (accessed 14 June 2021).

Tlemsani, S. and Suwaidi, H. (2016), "Comparative analysis of Islamic and conventional banks in the UAE during the financial crisis", Asian Economic and Financial Review, Vol. 6 No. 6, pp. 298-306.

Usman, A. and Khan, M.K. (2012), "Evaluating the financial performance of Islamic and conventional banks of Pakistan: a comparative analysis", International Journal of Business and Social Science, Vol. 3 No. 7, pp. 1-5.

Widagdo, K.A. and Ika, S.R. (2008), "The interest prohibition and financial performance of Islamic banks: Indonesian evidence”, International Business Research, Vol. 1 No. 3, pp. 1-12.

\footnotetext{
About the authors

Muhammad Tariq Majeed, $\mathrm{PhD}$, is an Associate Professor (Tenured) of Economics at Quaid-i-Azam University, Pakistan. He received his PhD in Economics from University of Glasgow, UK. Muhammad Tariq Majeed is the corresponding author and can be contacted at: tariq@qau.edu.pk

Abida Zainab worked as a Research Associate in a Project "Center for Social Entrepreneurship" at the Ministry of Planning, Development and Reforms, Planning Commission Islamabad, Pakistan. Islamic Finance, Development Economics and Applied Economics are her research interests.
}

For instructions on how to order reprints of this article, please visit our website:

www.emeraldgrouppublishing.com/licensing/reprints.htm

Or contact us for further details: permissions@emeraldinsight.com 